\title{
Pharmacognostic Investigation of Clerodendrum phlomidis Linn. f. Root
}

\author{
Dinesh Kumar1*, Ajay Kumar¹, Om Prakash² \\ ${ }^{1}$ Institute of Pharmaceutical Sciences, Kurukshetra University, Kurukshetra-136119, India \\ ${ }^{2}$ Manav Bharti University, Solan-173229, Himachal Pradesh, India
}

\begin{abstract}
The present study was aimed to perform the pharmacognostic evaluation of Clerodendrum phlomidis Linn. f. root in terms of organoleptic, fluorescence analysis, macro-microscopy and physicochemical parameters. The characteristic macroscopic study showed that the root consists of $7-15 \mathrm{~cm}$ long, 0.2 $3.0 \mathrm{~cm}$ thick pieces which are cylindrical, tough and yellowish-brown externally, with hard fracture and slightly astringent taste. The main microscopic characters of the root show exfoliating cork, having 1015 rows of tangentially elongated, thick-walled cells. Cortex consists of round to oval parenchymatous cells, a few containing rhomboid shaped calcium oxalate crystals. Endodermis consists of 3-4 layers of non-lignified, thick-walled rounded parenchymatous cells followed by a single pericyclic layer. Phloem consists of isodiametric, thin-walled, parenchymatous cells whereas xylem contains lignified pitted vessels. Medullary rays consisting of biseriate layer of lignified and radially elongated parenchymatous cells is narrower in the xylem region during wider in the phloem region. The physicochemical analysis of the root, i.e., total ash, water-soluble ash, sulphated ash are 7.8, 0.9 and $10.3(\% \mathrm{w} / \mathrm{w})$ respectively. Further successive extraction of the root powder with petroleum ether, chloroform, alcohol, water yielded 2.2, 2.4, 12.4 and $9.6(\% \mathrm{w} / \mathrm{w})$ extracts respectively. Fluorescence study imparted characteristic colours to the root powder when observed under visible, short and long wavelength light. Various pharmacognostic parameters evaluated in this study helps in botanical identification and standardization of Clerodendrum phlomidis L. root part in crude form and provide the authentic data for the researchers and scientists involved in carrying out further research on this plant part.
\end{abstract}

Keywords: Clerodendrum phlomidis L., Microscopy, Physico-chemical, Fluorescence analysis

\section{INTRODUCTION}

Clerodendrum phlomidis Linn. f. (Family: Verbenaceae), known as Wind-killer or Arni in Hindi, is a common shrub of barren plains, low hills and tropical deserts, distributed more or less throughout India, Myanmar, Pakistan, Sri Lanka and south-east Asia [1,2]. Traditionally, C. phlomidis L. is effectively used in treating bronchitis, headache, inflammation, weakness, drowsiness, digestive problems and joint pains [3,4]. C. phlomidis has shown antidiarrhoeal [5], antifungal, antiam-nesic, antidiabetic and antihepatotoxic activities [6-9]. Phytochemical analysis of this plant has reported

*Corresponding author:

Dinesh Kumar

Institute of Pharmaceutical Sciences, Kurukshetra University,

Kurukshetra-136119, Haryana, India

E-mail: dineshbarbola@yahoo.co.in various constituents like $\beta$-sitosterol, ceryl alcohol, scutellarein, pectolinaringenin, $\gamma$-sitosterol, clerodin, clerosterol, clerodendrin-A, apige-nin, hispidulin, luteolin, $\alpha$-L-rhamnopyranosyl- $(1 \rightarrow 2)$ $\alpha$-D-glucopyranosyl-7-O-naringin-4'-O- $\alpha$ D-glucopyranoside-5-methylether, Lup-20(29)-en-3triacontanoate, tetratriacontanol, 24ß-ethyl-cholesta-5,22E, 25-triene-3 $\beta$-ol [10-15]. In the present study, Pharmacognostical investigations have been carried out on the roots of Clerodendrum phlomidis L. to describe the parameters useful for the characterization and standardization of this drug part both in scraped and powdered form.

\section{MATERIALS AND METHODS}

\section{Chemicals}


All the chemicals and reagents used in this study were of analytical grade and procured from Rankem Limited India and Hi-Media laboratories, Mumbai, India.

\section{Collection of Plant materials}

The plant material (roots) were collected from the campus of Kurukshetra University, Kurukshetra during April 2011 and authenticated by Dr. H.B Singh, NISCAIR (NISCAIR/RHMD/ Consult/-2010-11/1471/69).

\section{Macroscopic evaluation}

Various organoleptic and macroscopic characters like color, shape, size, taste, odor, fracture and configuration, etc. of $C$. phlomidis L. root were studied and compared with available data [16].

\section{Microscopic evaluation}

Microscopic studies were performed qualitatively and quantitatively with the help of a compound microscope [Model: SKC-400, Suswox Optik, Sudheer Scientific Works, India].

\section{Qualitative microscopy}

In this study, transverse sections of root were examined under photographic compound microscope. Phloroglucinol and conc. Hydrochloric acid in the ratio $1: 1$ were used as staining reagents. The several identifying features of the drug were studied with or without staining and recorded as per already reported methods $[17,18]$.

\section{Root microscopy}

Few fine root samples immersed in a test tube containing sufficient water and boiled for few minutes. Thereafter, the softened pieces were transversally cut into fine sections, stained with staining reagent $0.1 \% \mathrm{w} / \mathrm{v}$ phloroglucinol followed by concentrated hydrochloric acid. The stained sections were observed for different layers of cells/ tissues and recorded other identifying features photomicrographic $[19,20]$.

\section{Powder microscopy}

To a small amount of root powder taken over a microscopic slide, $1-2$ drops of $0.1 \% \mathrm{w} / \mathrm{v}$ phloroglucinol and concentrated hydrochloric acid (1:1) were added, mixed well, covered with a cover slip and examined. Various identifying featu- res of cell components were observed and recorded using photomicrograph [21].

\section{Fluorescence analysis}

Powdered root was treated with various chemical reagents and observed under ultraviolet light (short and long wavelength) to study its fluorescence behavior as per reported procedure [22]. To small quantity of the powder taken on clean microscopic slide, 1-2 drops of the freshly prepared reagent phloroglucinol and concentrated hydrochloric acid (1:1) solution were added, mixed and kept aside for 1-2 minutes. Thereafter, the slide was observed in visible light, short (254 $\mathrm{nm})$ and long $(365 \mathrm{~nm})$ ultraviolet radiations where the colors observed by application of different reagents in different radiations were recorded.

\section{Physicochemical analysis}

In this study, root powder was evaluated for the determination of physicochemical conditions as loss on drying, total ash, acid insoluble ash, water-soluble ash, sulphated ash and extractive values as per reported method [23].

\section{RESULTS}

\section{Macroscopic study of root}

Macroscopic examination of the root (Figure 1) shows that it consists of $7-15 \mathrm{~cm}$ long and 0.2 $-3.0 \mathrm{~cm}$ thick pieces which are occasionally branched, cylindrical, tough, yellowish-brown externally, thin bark, the outer surface rough due to exfoliation, with hard fracture and slightly astringent taste.

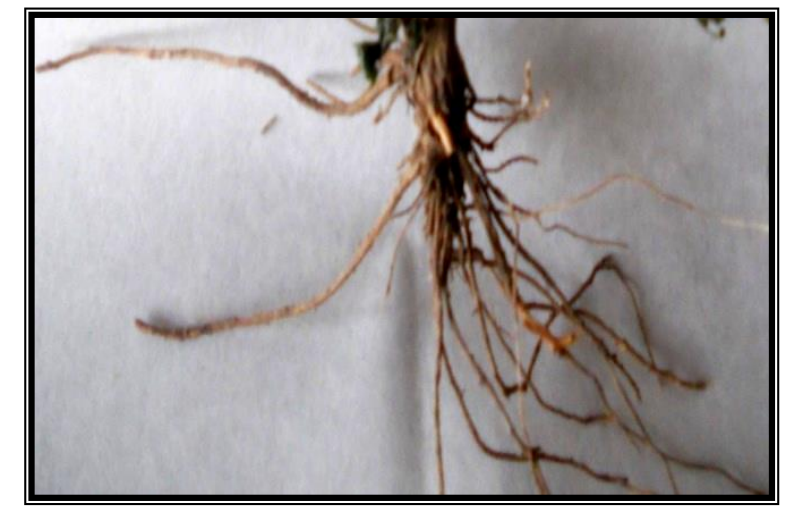

Figure 1. Image of Clerodendron phlomidis root 


\section{Microscopic study of root}

Transverse section of the root (Figure 2) shows exfoliating cork, consisting of about 10-15 layers of tangentially elongated, thick-walled cells. Cortex consists of round to oval parenchymatous

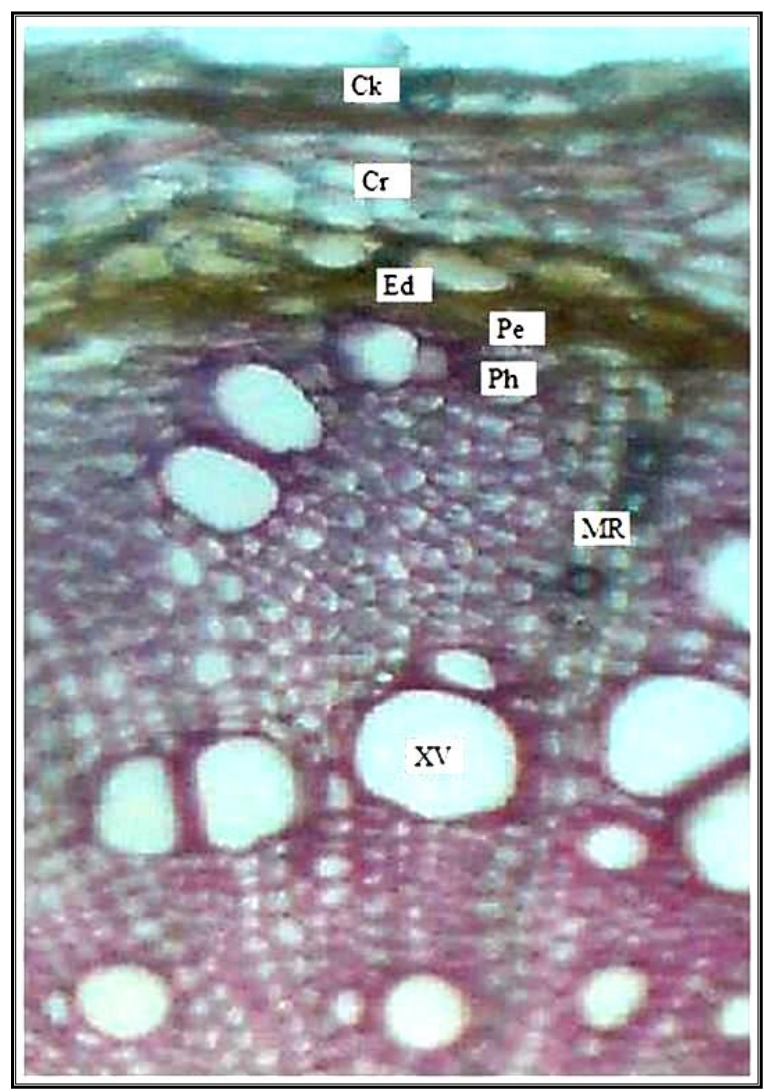

Figure 2. T.S. of C. phlomidis Linn. root; $\mathbf{C r}$ - Cork, $\mathbf{C k}$ Cortex, Ed-Endodermis, Pe-Pericycle Ph-Phloem, $\mathbf{X V}$-Xylem vessel, $\mathbf{M R}$-Medullary rays

cells, a few containing rhomboid shaped calcium oxalate crystals. Endodermis consists of 3-4 layers of non-lignified, thick-walled rounded parenchymatous cells. Pericycle consists of a single layer of non-lignified, thin-walled rounded parenchymatous cells below the endodermis. Phloem consists of isodiametric, thin-walled, parenchymatous cells, a few containing rhomboid crystals of calcium oxalate. Xylem shows a wide zone, consisting of lignified pitted vessels found in single as well as in a group of 2-3 scattered throughout xylem region. Medullary rays, narrower in the xylem region and wider in the phloem region, consist of biseriate, lignified and radially elongated parenchymatous cells.

\section{Powder study, Fluorescence analysis and Physicochemical analysis}

Root powder appears dull yellow, showing fragments of cork cells about 2-3 rows of tangentially elongated, thick-walled cells. Cortex consists of thin-walled round to oval parenchymatous cells, lignified and pitted xylem vessels (60.25-145.6 $\mu$ ), non-lignified sieve tube and rhomboid shaped calcium oxalate crystals measuring 12 to $24 \mu$ in length and 6 to $15 \mu$ in width. Powder characteristics of the root have been shown in Figure 3. The fluorescence observations of the root powder with different chemical reagents are summarized in Table 1. In this study, various physicochemical parameters like loss on drying, total ash, acid insoluble ash, water-soluble ash, sulphated ash and extractive values were determined in triplicate as mentioned in Table 2.

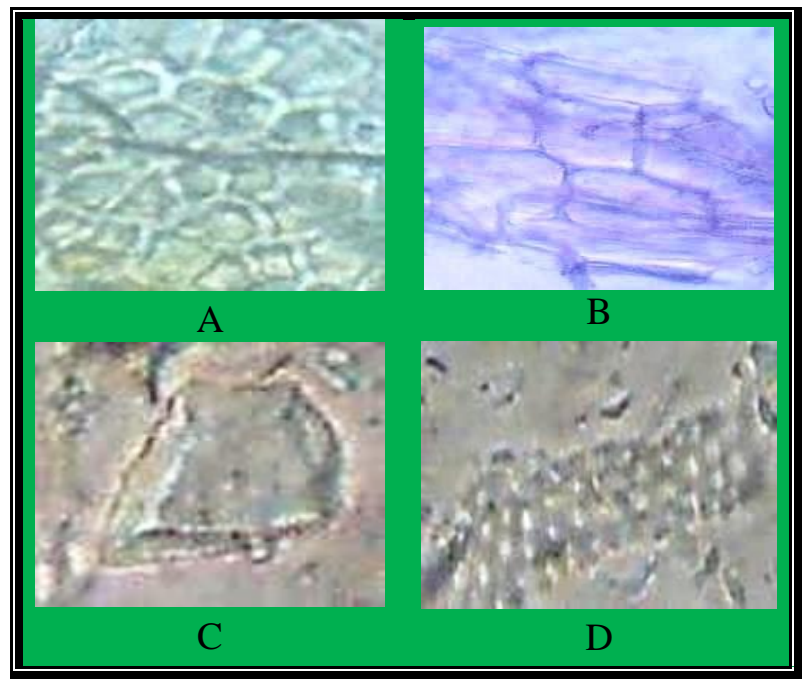

Figure 3. Powder characteristics of C. phlomidis root (ACork cells; B-Cortex cells; C-Calcium oxalate crystal; D-Xylem vessel)

\section{DISCUSSION}

Most of the crude drugs obtained from wild sources are usually collected by poor and illiterate people unaware to botanical identification, authentication and standardization of crude drugs. As the plant products are multifaceted due to their heterogeneous composition, the standardization is often a complex assignment. To ensure the superiority of herbal medicines, appropriate control of starting material is extremely crucial. The first step for assuring quality of starting material is its authentication that may be followed 
by developing numerical values of standards for assessment [24,25]. Pharmacognostical evaluation of different parameters is the vital etiquette for standardization of herbals [26].

Table 1. Fluorescence analysis of C. phlomidis L. root powder

\begin{tabular}{|c|c|c|c|}
\hline \multirow[b]{2}{*}{ Treatment } & \multirow[b]{2}{*}{ Visible light } & \multicolumn{2}{|c|}{ Under UV light } \\
\hline & & $\begin{array}{c}\text { Short } \\
\text { Wavelength } \\
(254 \mathrm{~nm})\end{array}$ & $\begin{array}{c}\text { Long } \\
\text { wavelength } \\
(365 \mathrm{~nm})\end{array}$ \\
\hline Powder & $\begin{array}{l}\text { Yellowish } \\
\text { brown }\end{array}$ & Pale green & Brown \\
\hline $\begin{array}{c}\text { Powder }+1 \mathrm{~N} N \mathrm{NaOH} \\
\text { (aq.) }\end{array}$ & Light brown & Green & Brownish green \\
\hline $\begin{array}{c}\text { Powder }+1 \mathrm{~N} N \mathrm{NaOH} \\
\text { (alc.) }\end{array}$ & Light yellow & Dark green & Yellowish green \\
\hline Powder + Ammonia & Light yellow & Green & Yellowish green \\
\hline Powder + Picric acid & $\begin{array}{l}\text { Yellowish } \\
\text { brown }\end{array}$ & Green & Dark brown \\
\hline Powder + Pet. ether & Light brown & Light green & Pale green \\
\hline Powder $+50 \% \mathrm{HCl}$ & Light brown & Green & Pale yellow \\
\hline Powder $+50 \% \mathrm{H}_{2} \mathrm{SO}_{4}$ & Brown & Greenish brown & Brownish \\
\hline
\end{tabular}

The present study lays down the pharmacognostical parameters of C.phlomidis root and its results are incommensurate with those of previous studies [27]. The morphological parameters like shape, size, colour and microscopic characteristics of the root such as rhomboid shaped calcium oxalate crystals, biseriate medullary rays, etc. help in identification of exact species and avoid adulteration. The total ash is particularly important in the evaluation of purity of drugs i.e. presence or absence of foreign inorganic matter such as metallic salts and/or silica [28]. The present study on the pharmacognostic evaluation and physicochemical parameters of the C. phlomidis root might be useful to supplement information with regard to its identification

Table 2. Physicochemical analysis of $C$. phlomidis L. root

\begin{tabular}{|lc|}
\hline \multirow{1}{*}{ Parameters } & Value obtained on dry \\
\cline { 2 - 3 } & weight basis $(\% \mathrm{w} / \mathrm{w})^{*}$ \\
\hline Loss on drying & $12.21 \pm 0.16$ \\
Total Ash Value & $10.94 \pm 0.23$ \\
Acid insoluble ash & $1.47 \pm 0.37$ \\
value & \\
Water soluble ash & $1.96 \pm 0.12$ \\
Sulphated ash & $15.8 \pm 0.04$ \\
Water soluble & $18.4 \pm 0.27$ \\
extractive & \\
\hline
\end{tabular}

\begin{tabular}{|c|c|}
\hline $\begin{array}{l}\text { Alcohol soluble } \\
\text { extractive }\end{array}$ & $9.6 \pm 0.04$ \\
\hline
\end{tabular}

*Average of three reading \pm SEM

parameters. The informationse are considered significant for the acceptability of herbal drugs in the present scenario. Fluorescence study of the root powder helps in the qualitative study of steroids which can be used as a reference data for the identification of adulterations.

\section{CONCLUSION}

The detailed pharmacognostic study on $C$. phlomidis root would be of high value in the identification, quality control, and formulation development. These data obtained pooled together will help in the proper identification and authentication as well as differentiate from its related species.

\section{ACKNOWLEDGEMENT}

The authors express sincere thanks to UGC, New Delhi (39-955/2010 SR) for financially supported the study.

\section{REFERENCES}


1. Matthew KM (1991) An Excursion Flora of Central Tamilnadu, India. New Delhi, India: Oxford and IBH Publishing Co.

2. Kritikar KR, Basu BD (2005) Indian Medicinal Plants. 3 ${ }^{\text {rd }}$ Vol. Dehradun: International Book Distributors and Publication.

3. Nadkarni KM (1976) Indian Materia Medica. Bombay, India: Popular Prakashan Pvt. Ltd.

4. Meena AK, Rao MM (2010) Folk Herbal Medicines Used by the Meena Community in Rajasthan. Asian J Tradit Med. 5: 1-13.

5. Rani S, Ahamed N, Rajaram S, et al (1999) Antidiarrhoeal Evaluation of Clerodendrum phlomidis Linn. Leaf Extract in Rats. J Ethnopharmacol. 68: 315-319.

6. Rajasekaran A, Ponnusamy K (2006) Antifungal activity of Clerodendron inerme (L) and Clerodendron phlomidis (L). Turk J Biol. 30: 139-142.

7. Joshi H, Megeri K (2008) Antiamnesic Evaluation of C. phlomidis Linn. Bark Extract in Mice. Braz J Pharm Sci. 44: 717-725.

8. Dhanabal SP, Mohan Marugaraja MK, Suresh B (2008) Antidiabetic Activity of Clerodendron phlomoidis Leaf Extract in Alloxan-Induced Diabetic Rats. Indian J Pharm Sci. 70: 841-844.

9. Verma A, Ahmed B (2009) Anti-hepatotoxic Activity of Clerodendrum Phlomidis. Int J PharmTech Res. 1: 1027-1031.

10. Gupta SK, Chandra S, Mahadevan V (1967) Chemical Examination of Clerodendron phlomidis. Indian J Pharm. 28: 102-106.

11. Subramanium SS, Nair AGR (1972) Scutellarein and Pectolinaringenin from the Leaves of Clerodendrum phlomidis and Duranta repens. Phytochemistry. 11, 3095-3096.

12. Joshi KC, Singh P, Mehra A (1979) Chemical Investigation of the Roots of Different Clerodendron species. Planta Med. 37: 64-66.

13. Seth KK, Pandey VB, Dasgupta B (1982) Flavonoids of Clerodendron phlomidis Flowers. Pharmazie. 37: 74-75.

14. Anam EM (1999) Novel Flavanone and Chalcone Glycosides from Clerodendron phlomidis (Verbenaceae). Indian J Chem. 38B: 1307-1310.
15. Pandey R, Kaur, Malasoni R, et al (2008) Lupeol Ester from Clerodendron phlomidis. Indian J Chem. 47B: 470-472.

16. Khatoon S, Singh N, Kumar S, et al (2009) Authentification and Evaluation of an Important Ayurvedic Drug - Ashoka bark. Indian J Tradit Knowl. 68: 393-400.

17. Kokate CK (2010) Practical Pharmacognosy. $4^{\text {th }}$ ed. New Delhi: Vallabh Prakashan

18. Bisht A, Zaman K, Singh M, et al (2011) Pharmacognostical Studies on Oroxylum indicum (Linn.) Vent. Stem Bark. Indian J Nat Prod Resour. 2: 472-478.

19. Ahmed F, Urooj A (2011) Pharmacognostical Studies on Ficus racemosa Stem Bark. Pharmacog J. 3: 19-24.

20. Bhide B, Acharya RN, Naria P, et al (2011) Pharmacognostic Evaluation of Cordia macleodii Hook. stem bark. Pharmacog J. 3: 49-53.

21. Khandelwal KR (2011) Practical Pharmacognosy. $21^{\text {th }}$ ed. Pune: Nirali Prakashan.

22. Kokashi C J, Kokashi RJ, Sharma M (1958) Fluorescence of Powdered Vegetable Drugs in Ultraviolet Radiation. J Am Pharm Assoc. 47: 715-717.

23. WHO/QCMMPM (1992) Quality Control Methods for Medicinal Plant Materials. Geneva: Organisation Mondiale De La Sante.

24. Sandhya S, Venkatramana K, Vinod K R, et al (2011) Pharmacognostical standardization of Tephrosia maxima Pers root. Pharmacog J. 3: 2533.

25. Chellappan DR, Joseph J, Balasubramanian P (2011) Pharmacognostical, Antioxidant and Antiulcer Screening of Cyclea peltata roots. Braz J Pharmacogn, 21: 1096-1103.

26. Johansen DA (1940) Plant microtechnique. New York: McGraw Hill Book Co.

27. Kahraman A, Celep F, Dogan M (2010) Anatomy, trichome morphology and palynology of Salvia chrysophylla Stapf (Lamiaceae). South Afr J Bot. 76: 187-195.

28. Musa KY, Katsayal AU, Ahmed A, et al (2006) Pharmacognostic investigation of the leaves of Gisekia pharnacioides. Afr J Biotechnol. 5: 956-957. 